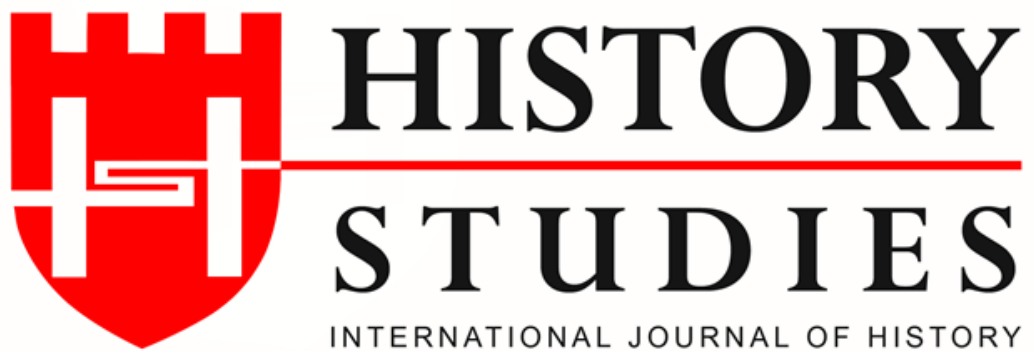

ISSN: 13094173 / (Online) 1309 - 4688 (Print)

Volume: 13, Issue: 4, August 2021

www.historystudies.net

\title{
FELLAHEEN SMUGGLING FROM THE MOUNT LEBANON
}

\author{
Cebel-i Lübnan'dan Fellah Kaçakçılığı
Dr. Arş. Gör. Meryem Günaydın
Firat Üniversitesi
mgnydn@yahoo.com
ORCID ID: 0000-0002-3957-1471

\begin{abstract}
Makale Türü-Article Type
Geliş Tarihi-Received Date

Kabul Tarihi-Accepted Date

DOI Number
\end{abstract}

\author{
Araștırma Makalesi-Research Article \\ 07.05.2021 \\ 28.08.2021 \\ 10.9737/hist.2021.1034
}



HISTORY STUDIES

Uluslararası Tarih Araştırmaları Dergisi

International Journal of History

13/4, Ağustos - August 2021

1259-1277

Araştırma Makalesi

\section{FELLAHEEN SMUGGLING FROM THE MOUNT LEBANON}

Cebel-i Lübnan’dan Fellah Kaçakçılığı

\section{Dr. Arş. Gör. Meryem Günaydın}

\section{Öz}

19. yüzyılda Amerika'ya başlayan büyük ölçekli göç akımına Cebelli fellahlar da katılmıştır. Cebel-i Lübnan ahalisinden fellahların Amerika'ya firarları karadan limana ve limandan vapura uzanan organize bir kaçakçılık sonucunda gerçekleşmiştir. Giderek artan fellah göçü İstanbul ve Beyrut arasında yazışmaların odağı haline gelmiştir. Fellah kaçakçılığıla mücadele için bir dizi yeni muamele ve tedbirler gündeme gelmiş ve uygulanmıştır.

Cebel-i Lübnan'dan Amerika veya diğer yabancı memleketlere doğru gerçekleşen göç akımları içerisinde ekinci köylülerin yani fellahların göçleri ayrı bir öneme sahiptir. $\mathrm{Bu}$ göçün seyrini anlamak açısından konunun incelenmesi amaçlanmış olup bu çalışmada alınan tedbirler ile etkileri üzerinden fellah kaçakçılığının öyküsü açıklanacaktır.

Anahtar Kelimeler: Fellah, Cebel-i Lübnan, Amerika, Beyrut, Kaçakçılık

\section{Abstract}

Fellaheen from Mount Lebanon joined the largescale immigration flow that started in America in the 19th century, too. The flight of fellaheen from the people of Mount Lebanon to America was the result of an organized smuggling from land to port and port to ferry. The increasing fellah migration has become the focus of correspondence between Istanbul and Beirut. A number of new procedures and measures have been brought to the agenda and implemented to combat fellah trafficking.

In the migration flows from Mount Lebanon to America or other foreign countries, the immigration of the rural cultivators, namely the fellaheen, has a special importance. In order to understand the course of this migration, it is aimed to examine the subject, and the story of fellah smuggling will be explained through the measures taken and its effects in this study.

Keywords: Fellaheen, Mount Lebanon, America, Beirut, Smuggling 


\section{Introduction}

The increasing number of Ottoman subjects immigrating to America has reached remarkable numbers. An American traveler, who had visited the Syrian directions in 1893, stated that eight to ten thousand people from Mount Lebanon and surrounding neighborhoods were said to have gone to America. ${ }^{1}$ Earning a lot of money in a short time ${ }^{2}$ and the desire to make wealth like those who went before ${ }^{3}$ has been seen as the general reason for their immigration to America.

Since the 19th century, large-scale migration movement from Syria to America has started. The Syrian people also migrated to Latin American countries. The most important driving factor in Syrian migration is the socio-economic deterioration seen after $1860 .{ }^{4}$ In addition, economic conditions and the compulsory military service pushed to immigration.

In general, economic activities in this region have begun to change the social life of the people of the region. The agriculture of Syria, which was a primitive and simple agriculture in which modern agricultural tools were unknown, was not open to agricultural progress. The lack of road transportation to facilitate trade and agriculture in the inner regions has been another important obstacle to agricultural activities. At the beginning of the 20th century, the introduction of the Hejaz railway line in the Syria-Lebanon region contributed to transportation, and agriculture and crafts had the opportunity to open up to foreign trade. Thus, transportation between the port and the inner parts has become easier. Especially since the middle of the 19th century, investments in the field of industry and technology, seen in Europe and other regions of the Ottoman Empire, and the improvement of agriculture were implemented in this region as well. The use of electricity in lighting, tram and railway enterprises, improvement of weaving looms, construction of medical schools and new hospitals, establishment of sample farms, more efficient use of rivers are the development moves of the Ottoman Empire for the people of the region to lead a more prosperous life. ${ }^{5}$ However, the decline in other industries, together with weaving, in which Europeans are active, has had an increasing effect on out-migration movements. ${ }^{6}$ The deterioration in the socioeconomic structure, which occurred as a result of the economic changes that were also effective on the peasant producers, gave rise to the most important driving reasons of the outward migration movement. It can be assumed that inclusion in the economic market, as well as the driving force created by the economic structure, makes Lebanese more aware of the outside world and its possibilities and more ready to think about emigration. ${ }^{7}$ In addition, social conflicts and uprisings in the 1840s and 1850s encouraged immigration from Lebanon. ${ }^{8}$ In the United States, high wages are the most important attracting force for immigrants. ${ }^{9}$ The money sent by the immigrants to their homes or the capital they brought back to their hometowns has been an important source of motivation for those who want to migrate. As a result, the factors accompanying the economic and social transformation have also accelerated the migration movement.

The migrations of fellaheen from Mount Lebanon have specific driving factors as well as general causes. According to this; as a result of two emergences in the 19th century, the peasants

\footnotetext{
${ }^{1}$ BOA.HR.ID.14/66 Lef 3

${ }^{2}$ BOA.HR.ID. $15 / 17$

${ }^{3}$ BOA.DH.TMIK.M.65/56

${ }^{4}$ Meryem Günaydın, "Osmanlı Döneminde Suriye Havalisinden Amerika'ya Göçler”, Journal of The Center for Ottoman Studies, Ankara University, 46 /Fall 2019, p.134.

5 Başbakanlık Devlet Arşivleri Genel Müdürlüğü Osmanlı Arşivi Daire Başkanlığı, Osmanlı Belgelerinde Suriye, Publication issue: 129, İstanbul 2013, p. 4-5.

${ }^{6}$ Gabriel Baer, Fellah and Townsman in the Middle East Studies in Social History, Frank Cass, London 1982, p.80.

${ }^{7}$ Charles Issawi, The Economic History of the Middle East 1800-1914 A book of Readings, The University of Chicago Press, Chicago: 1966, p.26.

${ }^{8}$ Issawi, ibid, p. 30.

${ }^{9}$ Leland James Gordon, American Relations With Turkey 1830-1930 An Economic Interpretation, University of Pennsylvania Press, 1932, s.300.
} 
were crushed under the burden of debt. Firstly, with the transition to export products (such as rice and cotton), money taxes gradually replaced the payment of in-kind taxes, and from 1880 only cash payment was recognized by law. ${ }^{10}$ Secondly, in the 19th century, the need for credit emerged after the transition to market oriented production. In other words, the transition to a money economy caused usurers who were not involved in the rural subsistence economy to enter the village. There has been an increase in the indebtedness of the villagers who cannot pay their taxes. Thus, the domination of the usurers has arisen over the farmers.

Another important development was the decline in silk production in Mount Lebanon in the early 20th century. Because of France's silk imports from China ${ }^{11}$ trade activities based on silk imports in the region were negatively affected and Syrian silk declined in the world market. Changing economic activities have begun to change the social life of the local population. In general, Christians who controlled silk production in the region were affected by this decline.

The immigration of the fellaheen from Mount Lebanon was prohibited and tried to be controlled, but the measures taken could not prevent the migration flow of the fellahs. The fellaheen continued their fugitive migration through a number of smugglers who helped them and who had acquired this as a profession. In this context, fellah smuggling is important as an example of illegal immigration.

In terms of their numbers, the migration of Mount Lebanon fellaheen ${ }^{12}$ to America and other countries is a separate wave within the general migration movement. According to American immigration statistics, a total of 56,909 Syrians and 12,954 Turkish immigrants were accepted between 1899-1910. ${ }^{13}$ When the distribution statistics of the accepted immigrants among these (did not separate women and men) has been examined according to their professions, it was seen that immigrants in the agricultural worker and farm worker category were more than other professions. The table about this is as follows:

Table 1: Numbers of immigrant admitted to the United States reporting each specified occupation, fiscal years 1899 to 1910 by race or people ${ }^{14}$

\begin{tabular}{|c|c|c|c|c|c|c|c|}
\cline { 3 - 7 } \multicolumn{2}{c|}{} & \multicolumn{6}{c|}{ Number Who were } \\
\hline $\begin{array}{c}\text { Race or } \\
\text { people }\end{array}$ & $\begin{array}{c}\text { Total } \\
\text { number } \\
\text { of } \\
\text { immi- } \\
\text { grants } \\
\text { Sional } \\
\text { occupa- } \\
\text { tions } \\
\text { Syrian }\end{array}$ & $\begin{array}{c}\text { In Profes- } \\
\text { s6.909 }\end{array}$ & $\begin{array}{c}\text { In skilled } \\
\text { occupa- } \\
\text { tions }\end{array}$ & $\begin{array}{c}\text { Farm } \\
\text { laborers }\end{array}$ & Laborers & $\begin{array}{c}\text { In other } \\
\text { occupa- } \\
\text { tions }\end{array}$ & $\begin{array}{c}\text { Without } \\
\text { occupa- } \\
\text { ions } \\
\text { (icluding } \\
\text { women } \\
\text { and } \\
\text { children) }\end{array}$ \\
\hline Turkish & 12.954 & 133 & 865 & 3,899 & 5.393 & 1.351 & 1.313 \\
\hline
\end{tabular}

${ }^{10}$ Baer, ibid, p.69

${ }^{11}$ Akram Fouad Khater, Inventing Home Emigration, Gender, and the Middle Class in Lebanon 1870-1920, University of California Press, London, England 2001, p. 46.

${ }^{12}$ Fellah farmer, who sows and reaps crops, agriculturalist. İsmail Parlatır, Dictionary of Ottoman Turkish, Yarg1 Publishing House, Ankara 2009, p.447.

${ }^{13}$ Hale Şıvgın-Meryem Günaydın, "The Armenian Repatriation 1908-1914, The Question of Nationality and Property", Gazi Academic Review, 8(16), Ankara 2015, p. 17.

14 F. C. Croxton, Reports of Immigration Commissions Statistical Review of Immigration 1820-1910, Distribution of Immigrants 1850-1900, Washington: Government Printing Office, 1911, p.95

\author{
History Studies \\ www.historystudies.net
}


As a matter of fact; the farmers and fellaheen, who constitute the producer and cultivator of every society, were lost, regardless of the proportions in terms of both agricultural production and population.

\section{Migration of the Fellah Taifa}

The Sublime Porte has banned fellaheen from going to Europe and America for a long time. ${ }^{15}$ With the letter dated April 2, 1304 notified to Beirut and its surroundings, this ban was once again reiterated and confirmed. The Beirut government allocated some of the police and gendarmerie officers in Beirut to maintain this ban. Despite the ban, many reports were reported that some inhabitants and fellaheen from the Syrian province, Mount Lebanon and its surroundings were fleeing to America and other foreign countries. ${ }^{16}$ According to the telegrams that were received, the Lebanese people had escaped secretly, taking a tezkire on behalf of places such as Jaffa, Jerusalem, and Alexandria. ${ }^{17}$ It is known that as a result of the migrations that took place in this way that there was a decrease in military personnel, difficulties in the procurement of labor to be employed in agriculture, suspects of murder and those who were indebted to the state were lost. ${ }^{18}$ Therefore, it was reported that it was natural for the fellaheen in Syria, Beirut, Lebanon and Jerusalem to go for business purposes ${ }^{19}$ but they were forbidden to go to foreign countries without giving surety and guarantee. ${ }^{20}$

At the point of maintaining the ban, it was deemed necessary to take some measures upon the increase observed in the escapes of the fellaheen. ${ }^{21} \mathrm{~A}$ special commission was established for the preservation of the decision to ban immigration of the fellaheen to America and other foreign countries from the Mount Lebanon inhabitants. ${ }^{22}$

Arrangement in the "zeitun (olive) one tenth tax", which was seen as one of the most important reasons for the people to migrate, were put on the agenda. It was thought that the amendment of this tax and the guarantee and assurance of the trees that fully bear fruit would prevent migration, and this way, tree planting would be encouraged and popular. ${ }^{23}$

It was understood that all those who went to America from Mount Lebanon were from the non-Muslim poor and agriculturalist group and mostly from the "nüfus-u mektûme", that was, people who were not enrolled in the register. ${ }^{24}$ In order for such people to be given passports, first of all, they had to get Ottoman identity papers (Tezkire-i Osmaniye) with the registration of their population records, as well as taking the military service fee in full and with it, bail and assurance were required. Those who wanted to go to foreign countries had gone secretly as fugitives due to the absence of documents of identity and passage, the collection of military service fees for the past years, and the need to pay bail and security.

In order not to cause some corruption and escapes, it was found appropriate to task the unregistered non-Muslim population in the province with the military service fee starting from the enlistment date for it was not possible to collect the costs of the past years, to give one year in order to be pardoned from fines and past military costs, to make the registry processes for the population during this period but to give fines to those who did not register to the population

\footnotetext{
${ }^{15}$ BOA.ŞD. 2279/7

${ }^{16}$ BOA.BEO.2711/203258

${ }^{17}$ BOA.DH.TMIK.M.65/56

${ }^{18}$ BOA.BEO.3115/233601

${ }^{19}$ BOA.DH.ŞFR.288/27

${ }^{20}$ BOA.DH.MKT.2335/114

${ }^{21}$ BOA.BEO.2711/203258

22 BOA.DH.TMIK.M.65/56

${ }^{23}$ BOA.HR.ID. 15/51

${ }^{24}$ BOA.DH.MKT.2335/114
} 
during this period. Thus, both the unregistered non-Muslim population would be prevented from being kept secret and the military cost lost from the treasury would be ensured. In addition to these, the inconveniences that might occur due to their escape to foreign countries would have been prevented.

Despite the ban, many farmers and laborers, whose identities were not known, from the townspeople of Mount Lebanon and the province, went to America as "reminiscent of immigration". ${ }^{25}$ It was understood that they got on ferryboats from Beirut with mürûr tezkeresi (document of passage) to go to Alexandria, Port Said, Jaffa, Jerusalem and other Ottoman beaches. It has been understood that around 3800 people from the Beirut province migrated in April (1311), including four to five people who were Islamic and the remaining non-Muslims of Mount Lebanon (1311). However, even if their aim was to arrive to foreign countries, the detention of those who had the passage certificate taken to other Ottoman beaches and places such as Jaffa Jerusalem, Alexandria, Egypt, Cyprus, etc. did not apply to the regulation of movement. For this reason, it was thought that it was necessary to make it difficult for such people to receive mürûr tezkeresi with a new instruction. ${ }^{26}$ With this in mind, it was decided that those who want to go to America or other places in order to prevent the people of Mount Lebanon from going to the United States or other places are not given mürûr tezkeresi, and those who want to go to Egypt or Iskenderun for trade and art from the people of Mount Lebanon who want to go to the regions of Egypt or Iskenderun should take a bill from the guarantors, these people would be given an mürûr tezkeresi and, if they did not return, they would collect fifty Ottoman liras each as collateral from their guarantors. ${ }^{27}$

Even though the immigration ban was applied, the immigration ban was nothing more than a problem. Because, despite the ban, foreign ferries coming to the port of Beirut on regular voyages received a large number of Mount Lebanon fellaheen in secret and without permission. For example, in the letter sent to the Ministry of Internal Affairs dated 15 Rajab 1312, it was reported that the Messagerie company, which came to the port of Beirut, resisted the blocking of the police officers on the sea from Tripoli and Mount Lebanon coast by the Senegal ferry and departed from Beirut for a great number of fellaheen. ${ }^{28}$ Boatmen and similar vehicles who smuggled these fugitives continued to smuggle, ignoring the fines of three and five thousand each. In addition, the absence of military police on the beach facilitated the work of smugglers and brokers and enabled escape ${ }^{29}$ For this reason, a penalty was requested for those who would attempt to escape with two series of ferries to control the beaches, and those who would facilitate the escapes, by increasing the crew of the gendarmerie and police to ensure the prevention of fellah smuggling and to ensure public order ${ }^{30}$ For such escapes and the boatmen who mediate them, it was decided that the 112th, 113th and 114th articles of the Penal Code should be applied and the court's investigation and the necessary actions should be carried out and the steamers who accepted these fugitives should be treated in accordance with the passport regulations regarding the navy captains. $^{31}$

Since there is no legal punishment to be imposed on those who smuggled the fellah from Mount Lebanon, the local administration was always in trouble. For those who dare to smuggle, the publication of the provision of law was requested from the Beirut province. In response to this, with a record from the Council of State Civil Service (Şûrây-ı Devlet Mülkiye Dairesi), that

\footnotetext{
${ }^{25}$ BOA.DH.TMIK.M.252/29

${ }^{26}$ BOA.HR.ID. $15 / 17$

${ }^{27}$ BOA.HR.ID. 15/10 Lef 2

${ }^{28}$ BOA.BEO.551/41285 lef 2

${ }^{29}$ BOA.BEO.2711/203258

${ }^{30}$ BOA.DH.ŞFR.365/145

${ }^{31}$ BOA.BEO.551/41285
}

\author{
History Studies \\ www.historystudies.net
}


" those who are engaged in trade, art, and labor will be released by giving bail and guarantee and protecting their original nationality " reported to be suitable. ${ }^{32}$ However, it was declared that it was not permissible to declare a punishment order and law for those who would facilitate their escape.

In this regard, as per the 1926 numbered certificate of the Council of State Internal Affairs, due to the Syrian people fleeing to foreign countries with their mürur tezkiresi, "All the people of Mount Lebanon should not be permitted to America and Europe unless they are with the intention of trade or art and even those who want to get a mürur tezkiresi should be put on bail "method was adopted. ${ }^{33}$ This procedure covered the province of Syria together with the governorship of Mount Lebanon. However, it was decided not to allow the transition of those who were not declared bail in the mürur tezkeresi.

However, although the immigration of indigenous people to America was prohibited, it was observed that the central province was allowed to immigrate with some irregular practices. For example, it was reported that the passage of those who wanted to immigrate were permitted if they had provided official assistance for the industry school. ${ }^{34}$ Furthermore, according to the notification signed by Abdullah from Beirut, it was understood that Salih Efendi, the Civil Registrar of Beirut, prepared documents stating that they were settled in Mount Lebanon in order to save some people who were not related to Mount Lebanon from the military. ${ }^{35}$ In addition, it was noteworthy that some people did not apply to the registrars in the districts they were a member of, and received a copy of the mürur tezkeresi for Iskenderun from the central population administration. Upon such irregularities, persons were obliged to obtain a mürur tezkeresi and passport in the accidents they were affiliated with. Thus, it could be investigated whether there were debit relations with both the military and the state property since their identities would be known by their own locality. With this practice, it was thought that fellah smuggling would be prevented by not giving opportunities to smugglers, brokers and tipstaff of consular centers. ${ }^{36}$

The measures taken were proved to be insufficient because there was an organized illegal passenger transport from land to port and from port to ferry. Especially, French, Italian or Britishflagged ferries coming to Beirut took a large number of fellaheen as stowaways through brokers working for them. Considering that once every fifteen days, three-four hundred Syrians sail to European ports by ferries belonging to the companies in order to go to American ports ${ }^{37}$ it was understood that immigrant smuggling was a great source of income. During the migration season, which generally lasted from April to October, the French Postman Maritime and the Italian Rubattino Line earned 6 million francs annually from these immigrants to receive 250 to 230 francs of travel money from Syria to South America. ${ }^{38}$

The news that a large number of fellaheen were smuggled at night by the company ferryboats coming to the shores of Mount Lebanon was frequently conveyed to the government by the provinces. ${ }^{39}$ Among the archive documents, there are notices about companies carrying a large number of fellaheen such as on his return from Haifa to Beirut, the French Messagerie Senegal

\footnotetext{
32 "ticaret ve san'at ve amelelik ve emsal-i iş ile iştiğali ve tabiyyet-i asliyelerini muhafaza eylemek üzere kefalet ve teminat i'ta eden Cebellülerin ticaret, sanat için harice gidenlerin serbest bırakılmalarının” BOA. DH.TMIK.M. $65 / 56$

33 "Cebellilerin hiçbir şahsın ticaret veya sanat kasdlyla olmadıkça Amerika ve Avrupa'ya azimetine ruhsat verilmemeli ve mürur tezkiresi almak isteyenlerin dahi kefalet-i kaviyeye rabt edilmesi” "BOA.HR.ID.15/17

${ }^{34}$ BOA.BEO.3083/231194

35 BOA.DH.MKT.1198/25 Lef 4.

36 BOA.DH.TMIK.M.252/29

${ }^{37}$ BOA.HR.ID.15/17 Lef 2

${ }^{38}$ Issawi, ibid, p. 271.

${ }^{39}$ BOA.DH.SSFR.218/8
} 
ferry went to Tripoli and received 250 fellah fugitives, ${ }^{40}$ more than 150 fellaheen from Cyprus and over 200 people from Mount Lebanon took the ferry from Tripoli to Beirut secretly at night. ${ }^{41}$ There were 60 fellaheen on the Sant Ferry belonging to the Messagerie company that came to Beirut, and 45 fellaheen and others would be smuggled to America with the Italian company Oriyon ferry, among 45 soldiers off the coast of Tartus, within the Tripoli sanjak, ${ }^{42}$ the Beirut steamer of the Italian Company named Robanito was carrying the fellah around Beirut again. ${ }^{43}$ The French ferry departing from Latakia would have 200 fellah from Tripoli to go to America ${ }^{44}$ a number of fellah would be illegally boarded on the French ferry named Equator, ${ }^{45}$ many people from the Lebanese people of Mount Lebanon were put on the Armoni ferry of Italy to go to America ${ }^{46}$ According to the telegram received from the Kudus-u Sharif Police Department, there were 150 people from Mount Lebanon to go to America on the ship named Hun, of the Messagerie company $^{47}$ and Kok Company from Genoa to receive the fellah of Mount Lebanon through the broker Bikaldaganik. ${ }^{48}$

On the other hand, illegal passengers carried by the companies were collected on land by agents and brokers and brought to the beach and then transported to the open ferry in boats. Numerous events related to this were reported to Dersaadet (refers to Constantinople, means "door to happiness"). The deficiencies and the precautions that had to be taken as a result of each event were understood. In this context, the illegal passenger transport of ferries and the development stages of the measures taken for this emerge based on the events in the archive documents are revealed.

First of all, the next station which the ferryboats would visit if the company ferryboats taking fugitive passengers wishing to immigrate to America from the ports they came from were seen and could not be prevented were informed about the situation. For example, it was understood when the Messagerie Senegal Ferry, which was going to Dersaadet, returned from Haifa to Beirut, that it went to Tripoli and took 250 fellaheen fugitives upon its arrival in Beirut. It was reported by the commission that it took another 100 fellaheen, who were transferred to Dersaadet again by boats, on the ferry. ${ }^{49}$ When such ferries carrying illegal fellaheen arrived in Dersaadet, it was requested further action to be done by a reliable officer. ${ }^{50}$

Generally, the ferries belonging to the companies wandered for days along the beach outside their normal course and collected passengers. The inability to interfere with these ferries and the need for the permission of the relevant consulate to detect stowaways made the implementation of the ban difficult. Regarding this, the news that "The ferry known as Le Vitya, a member of the French Faber company, has sometimes been traveling between the neighborhoods for fifteen days and alongside the beaches where there are no cities and piers, and from those who want to escape to America, such as killers and thieves and deserters, took an estimated forty-fifty people to Iskenderun from there and has been trading this way for a while " ${ }^{51}$ was received. Since this situation was written to the French Consulate in Latakia and the ferry went to Iskenderun, it was requested that the passengers on this steamer be handed over to the Iskenderun government and

\footnotetext{
${ }^{40}$ BOA.DH.ŞFR.389/26

${ }^{41}$ BOA.DH.STFR. $218 / 8$

42 BOA.DH.TMIK.M.244/7

${ }^{43}$ BOA.DH.TMIK.M. 244/7 Lef 8

${ }^{44}$ BOA.Y.PRK.UM..67/75

${ }^{45}$ BOA.DH.TMIK.M.252 / 55

${ }^{46}$ BOA.HR.ID. $14 / 57$

${ }^{47}$ BOA.HR.ID. $15 / 15$

${ }^{48}$ BOA.DH.ŞFR.372/126

${ }^{49}$ BOA.DH.ŞFR.389/26

${ }^{50}$ BOA.DH.TMIK.M. 255/25

${ }^{51}$ BOA.HR.ID. 14/53
} 
that the French Embassy should be delivered to the relevant government if there were such men, but no response was received.

Similarly, a police officer was sent to control the ferry on its arrival in Iskenderun when it was heard from the Tripoli Police Commissariat, where many people from Mount Lebanon inhabitants boarded the Armoni ferry of Italy to go to America. While the wanted people were seen on the deck of the ferry, the police could not intervene on the ferry and immediately applied to the Italian Consulate. A tipstaff was sent over this. However, during the elapsed time, they could not reach the wanted people because they were hidden in the corners of the ferry. In this connection, it was stated that the embassy should send a notification to the consuls and ferry captains in order to enable the police and police officers to perform their duties immediately and not to prevent their duties. ${ }^{52}$ The necessary prosecution was made to prevent this situation that violated the ban, and the consulates were notified. Despite this, smuggling could not be prevented.

Upon this situation, Governor Halil urgently requested the allocation of two high-speed ferries. ${ }^{53}$ Thus, efforts has been made to increase the surveillance and control over the sea in order to prevent the ferries from buying illegal passengers.

Again, after unloading the cargo ships coming to the ports, they took many fugitive passengers secretly, especially at night, and transported them to the ports in Europe to go to America. It was not possible for the fugitives to be evacuated from cargo ships. ${ }^{54}$ Upon such cases, which was frequently encountered, it was decided to execute the punishment in accordance with the relevant law, with the transfer of the ship captains and boatmen belonging to the companies who came to the port of Beirut and secretly took a lot of the fellaheen from the shores of Mount Lebanon and smuggled the fugitives. ${ }^{55}$ It was ordered with reference to the decision of the Council of State Reform Arrangements that fines be imposed on ferries carrying fellaheen with and without a passport, and boatmen and similar vehicles who smuggled these passengers, and to treat ship captains who act contrary to the regulations in accordance with the passport regulations. ${ }^{56}$

Passengers were smuggled to the United States from Beirut, Tripoli and other ports on the Company ferries, as well as the importation and exportation of prohibited items. It was reported that the entire Tripoli navy from the Tripoli harbor chief was used to smuggling fellaheen and importing and exporting pistols, cartridges and other prohibited items. Although the smuggling of fellaheen with the import and export of such ammunition was prohibited by the order of the monarch (irade-i seniyye), they were exporting and importing whatever they wanted, along with the transportation of goods and passengers, from night to morning. Although this situation was reported to the local government, no benefit was seen. In order to avoid this, it was not given to practice after the day of sickness and the transport of goods after twelve in the evening was strictly prohibited. ${ }^{57}$ The Beirut province was notified to the military commission, the members of public order and the authorities responsible for the inspection of the Syrian coast, and the local port official was asked to be careful about not giving it to practice after sunset and preventing the transport of passengers and goods. On the other hand, since the surroundings of Beirut and Tripoli ports were open, it was declared that they could freely import and export from wherever they wanted, especially at night, as they wished. ${ }^{58}$

\footnotetext{
${ }^{52}$ BOA.HR.ID. $14 / 57$

${ }^{53}$ BOA.DH.TMIK.M.230/ 20

${ }^{54}$ BOA.HR.ID. $15 / 3$ Lef 4

${ }^{55}$ BOA.BEO 000551/41285

56 BOA.DH.MKT.277/47

${ }^{57}$ BOA.DH.TMIK.M. 222/8

${ }^{58}$ BOA.DH.TMIK.M.222 / 8
} 
In addition to fellah smuggling at Beirut, there were a number of people who adopted the trade of animal, ${ }^{59}$ passengers, weapons and prohibited goods as a profession. ${ }^{60}$ They mediated those who wanted to emigrate by escaping such that they became famous for their work. One of them was the person named "Hanny Fih", a broker residing in Beirut, who defrauded Syrians who wanted to go to America as an intermediary. Broker Hanni received a fee of three hundred sixty and four hundred crowns per person from many Syrians who would migrate to America, although he did not have the power of attorney and agency of the Cunard Line ferry company. He gave the tickets belonging to the company and sent the Syrians to Trieste. Although the per capita ferry fee was one hundred and twenty seven krones, the Syrians were charged a ferry fee of one hundred and eighty five for the transfer to the United States. It was reported that Syrians transferred by Consul of Trieste in this way were defrauded with fake tickets issued, some of them returned to Beirut, but the rest crawled on the streets and created a miserable sight. ${ }^{61}$

Mehmed Bizun is another one of the famous Beirutsmugglers. It was understood that Mehmed Bizun who were a grocer at the quarantine stationabducted the fugitive passengers and their accompanying harmful documents and weapons were smuggled from the quarantine wall from the beach at night and smuggled to Mount Lebanon with animals. This act of Mehmed Bizun was facilitated by the fact that there were no officers at the quarantine station pier for inspection at the arrival of the passengers. The exportation of Bizun from the grocery store and the appointment of a commission grocer of various classes to the pier were requested by Mirliva Faik from the Beirut Mobile Fleet Command, since he was smuggling weapons and animals. ${ }^{62}$

As a matter of fact, smuggling of passengers and forbidden goods was a common situation. It was run as an organized business by brokers, tipstaff and smugglers. The measures taken against the ferries resulting from this were insufficient at some point. Identifying and preventing collaborators in local offices who condoned these smugglers, along with those who acquired the art of smuggling, would make the implementation of the immigration prohibition convenient. Accordingly, it was aimed to find out which of the police, population, pier and police officers were allies with the brokers. ${ }^{63}$

The fact that the fellaheen of Mount Lebanon went to foreign countries in return for bribery, despite the ban, were seen behind the scenes in many cases. In the investigations carried out after the events, officers such as police officers, officers and municipal police who were in alliance with the smugglers were identified. For example, Selim Hozi Efendi, one of the Beirut police and foreign commissioners, was one of those who always brokered the chief inspector Cemal Bey to smuggle fellaheen to Europe and America. ${ }^{64}$ At night, Hasan Cob and Mehmed Çan took the fellahs of Mount Lebanon, who had gathered in an inn to escape to America, by boat and barge and took them to the ferry. Chief inspector Cemal Bey, who allied with the smugglers, allowed the fellaheen to board without encountering an obstruction by taking a bribe of French lira.

Allowing the abduction of fellaheen for money was found even before the Beirut Province Administrative Council as "a murderous crime.$^{65}$ Consequently, a meeting was conducted upon the transfer of the Council to the State and a penalty was decided for Selim Hozi according to the 67th and 68th article of the law on the grounds that he had bargained for bribery, for Cemal Bey according to the 67th and 68th articles. The penalty was decided also for lieutenant landowner Abdurrahmet and police Mir Sadettin and Mehmet Fehmi, Ömer Fethi Efendis and Sergeant

\footnotetext{
${ }^{59}$ BOA.DH.ŞFR.EUM. 4.BR 1/7, Lef 2

${ }^{60}$ BOA.BEO.3083/231194

${ }^{61}$ BOA.HR.ID. $15 / 55$

${ }^{62}$ BOA.Y.PRK.ASK.249/79

${ }^{63}$ BOA.DH.TMIK.M. 230 / 20

${ }^{64}$ BOA.ŞD. 2279/7

${ }^{65}$ BOA.ŞD. 2279/7
}

\author{
History Studies \\ www.historystudies.net
}


Engel for being against the orders of the state due to their participation with Cemal Bey according to the 99th article. Unfortunately, smuggling continued despite the penalties for the maintenance of the ban.

Smuggling was sometimes carried out by forming two-person societies. As an example; two brothers, Mahmud Münkare and Abuhadr Münkare, formed a bandit association. Together with some of the rabble who complied with them, they facilitated arms smuggling and the desertion of young people who had military service obligations to America. ${ }^{66}$ The people of Tripoli and the local administration are unable to acknowledge these people because some of the gendarmerie officers, who were police and postal officers, protected themselves and tolerated their actions in return for the aid they received from the bandits. However, since it would dare others not to punish these bandits, this state of affairs should have been completely resolved.

According to another letter signed by the informant and dated July 18, 328 from Tripoli, ${ }^{67}$ in Beirut, the boatmen Salih Zarif and Abu Ahmedcik, established an agency to help those who wanted to migrate from Beirut to America and to facilitate their migration in the administration of Amalibr(?). ${ }^{68}$ They profited from this by inappropriately giving tickets to America directly from Beirut. People who wanted to go to America were defrauded from time to time by these people.

Another example is broker Faris Assad Selame. With the 30-40 thousand francs he had somehow collected in America, Selame opened a money shop in Beirut and pretended to be a banker and immigration broker. He especially encouraged young people who had military obligations to go to America. It was reported that 1200 Syrians who wanted to go to America from Marseille Consulate bought two hundred and fifty francs from each and sent them to Marseille by giving them some papers instead of tickets. ${ }^{69}$ It was declared that Selame was continuing this action although the agency repeatedly informed that Selame would not accept the immigrant that Selame would send on his behalf, even though the immigration agency in Marseille named "Tesvine" on the tickets given by Simsar Selame. Also, the information that on behalf of the deputy of Faris Assad Selame, Kradi Liyon Bank received an amount as twenty thousand francs was shared. Syrian immigrants could not continue their journey with these fake tickets. Some of them were returned to their homeland, and some were roaming in Marseille, falling into misery, and it was reported that measures should be taken as soon as possible from the Marseille Consulate in order to end this improper situation.

The Paris Embassy warned against the boatmen "Salih Zarif" and "Abu Ahmedcik" in Beirut. They also formed an agency to facilitate the immigration of those who wish to immigrate to America from Beirut. ${ }^{70}$ They profited from this business by providing tickets to America directly from Beirut.

In a letter sent to the Foreign Affairs Ministry by Marseille Consulate, he announced the names of some of the Beirut boatmen who went to and from Marseille: Najib Elhas, Ibrahim Elmer, Nikola Asi, Jozef Nehas, Halil Timin, Mansur Nakozi, Şamil Kerem, Filib Terceman, Nikola Şemai, Bünyamin Bestami, Yusuf Sefai, Niam (?) Sabuncu, Reşid Şadyak, İlyas Manyar. ${ }^{71}$ Beirut boatmen carried out their illegitimate trade by traveling as passengers without having the necessary documents. The consolate mentioned that these boatmen had been committing abuse for a while. The boatmen accompanying those who immigrated to Marseille during the journey

\footnotetext{
${ }^{66}$ BOA.DH.H.21/67

${ }^{67}$ BOA.DH.H.21/67

${ }^{68}$ BOA.HR.SYS. $1529 / 99$

${ }^{69}$ BOA.HR.ID. $15 / 49$

${ }^{70}$ BOA.HR.SYS.1529/99

${ }^{71}$ BOA.DH.MKT.2753/2
} 
deceived them to stay in the hotels of the Syrian hoteliers in Marseille in exchange for the important bonuses given to them at the expense of the passengers. On their return, these individuals told immigrants from America that it was not necessary to get passports to go to their homeland, and they escorted themselves to the place they wanted to go in return for high sums by accompanying them on their travels. In this way, it was understood that they damaged the treasury. Reaching about a hundred people every week, the immigrant boatmen were not satisfied with their time and profits, but they also engaged in arms smuggling. They bought a large amount of rifles and cartridges and loaded them on the ferries as if they had been passengers' belongings. With the help of boatmen who were their friends in the port of Beirut, they acted to import these goods to the Ottoman lands. ${ }^{72}$

Reports from embassies regarding forbidden goods and arms smuggling were carefully evaluated. Based on the letter dated February 10,909 sent to the Paris embassy from the Marseille Consulate, the steamer named Avrenok would depart from Marseille on the fourth day of the current month and it was reported that eight boxes containing six parcels of prohibited goods and such items were loaded on the Italian-flagged "Governor" steamer. It was thought that the owner of six chests in the skin of the "Avrenok" steamer was someone named "Halil Timin" who was on board as a passenger. The smugglers transported them in passenger bags in order not to be suspicious of the ferry crew and to obtain their belongings whenever they wanted. Later, it was transported by transferring it to the boats waiting in the open. Preventing this trade was one of the duties of local officials and police officers. ${ }^{73}$ Likewise, Ali Ferruh and Tahsin Bey received a report about the smuggling of fifty thousand rifles and twenty thousand pistols and one million cartridges to Syria by the city of New York and the director of the El-Alem Newspaper, Corc Cebur. ${ }^{74}$ In another telegram of Cebur Efendi, he informed the London Embassy about the investigation of the Assyrian steamer that would come to Liverpol upon the claim that the weapons were made in the Vesister factory and sent from New York by the Asruria ferry.

As a result of finding the commissioners and police officers in Beirut jointly with the smugglers ${ }^{75}$ the fellaheen were allowed to escape in official offices such as ports and goods taxes. Thus, the measures taken in the wharves and ports to prevent smuggling completely and the time of the wharf commission remained ineffective. ${ }^{76}$ This situation was referred to in the 17 Ramadan 1329 edition of the newspaper "al-Müdellel" published in Tripoli. This article, in the form of a conversation between the three school students, was sent to the newspaper for publication by Hakk1, Sirrı and Abdullah. In the published article, it was mentioned that because hundreds of the young men who were obliged to military service of the fellaheen fled to foreign countries, that the pier police and even the officers who came from Beirut to investigate the officers who were partners with the smugglers allowed this in exchange for bribes, and the police chief who remained silent in this situation was in his own way with a woman named Meri Arab. ${ }^{77}$

There are numerous examples that leave no doubt that the wharf officers collaborated with smugglers, as clearly stated in the newspaper. For example, in order to take out the smugglers of Hadr, Ilyas Çelebi and their companion smuggled weapons from the ship that was waiting off the port of Beirut, the municipal lighthouses in the Respor (?) area in the east of the port were turned off by Mahmud Bayezut. Upon the act of denouncing the gendarmerie soldier, Latakia Mehmed,

\footnotetext{
72 BOA.DH.MKT.2753/2

${ }^{73}$ BOA.DH.MKT.2753/2

74 BOA.Y.EE.136/121

${ }^{75}$ Mustafa Öztürk, “19. Yüzyılın Sonları ile 20. Yüzyılın Başlarında Beyrut ve Çevresi”, Journal of Turkish Studies Turkish Studies, Festschrift in honor of Prof. Dr. Ozer Ergenç, Cemal Kafadar and Gönül A. Tekin (eds), Volume 52, Cambridge, December 2019, Mass: Harvard University Near Eastern Languages and Civilizations, p.173.

${ }^{76}$ BOA.BEO.3115/233601

${ }^{77}$ BOA.HR.TO.405/67
}

\author{
History Studies \\ www.historystudies.net
}


and the officers there, the commissioner Ramazan Efendi arrived at the scene. It was reported by the naval captain Nazif that a fisherman's boat, understood to be unattended and foreign, was coming from the sea to land and sailing to the port coal warehouse. ${ }^{78}$

Again, as a result of the research carried out by the Deputy Commander of the Gendarmerie Regiment and the Director of the Police, it was declared that Mülazım Abbas, police officers Reşid and Tahir Efendi, and Mustafa Efendi from the police officers, and Nesib from the gendarmerie sergeants had information and participation in the smuggling of fellaheen. ${ }^{79}$

In Beirut, because the police were in common with the smugglers in exchange for money, no action was taken against the smugglers, and smuggling continued to be carried out openly and audaciously. ${ }^{80}$ It was even observed that the fugitives in Mount Lebanon were released in exchange for money after they were caught. It was understood that 30 fellaheen and 65 people who passed to Sayda via Mount Lebanon were detained in Tripoli coffeehouse with only two gendarmes, but they were given the reason for their desertion again. ${ }^{81}$

Accordingly, in the letter number 89 of the Beirut Pier Commission, the cooperation between the officers on duty at the port and the smugglers was clearly explained ${ }^{82}$ According to this, it was stated that the Messagerie Congo ferry, which was in the port, was seen by the officer Captain Cemil, Police Commissioner Ramazan, Police Kemal and Abdürrahim Efendi to the pier commission where about thirty military obligations were smuggled by smuggler Mustafa, Mehmed Ferağıl Elçik and Ahmet Elçik. Fugitive military service officers were seen by the custodial officers of the Customs administration there that they were launched from the beach east of the quarantine office by these smugglers. The aforementioned illegal boats were tried to be prevented by the police officers Kemal and Abdürrahim, who were on duty in the boat, who were on duty to watch over the ferry, and the gendarme soldiers, while they were approaching the ferry. Ramazan Efendi and Nesib Sergeant left the ferry and returned to land. Police Abdürrahim Efendi shouted at the smugglers in order to cover up the crime but in response they said that "Why are you shouting? This smuggling was made within your knowledge and given money for it". ${ }^{3}$ Due to the attitude of the police officers who were on the beach and at sea for surveillance, the work of the pier commission was not rewarded.

Due to smuggling from some locations close to the quarantine beach outside the port, the police directorship was sent to the said location and the ferries under quarantine at anchored outside the port under surveillance, with a boat with police and gendarmerie, and a dinghy navy soldier by the naval command. Although it was thought that no smuggling was observed for a few days thanks to the control provided by the naval soldiers with the police station lifeboats, the fellaheen were taken to the ferry with about twenty to twenty-five illegal fellaheen under the administration of Ahmedcik. ${ }^{84}$ In addition, when the guard station lifeboats returned to the port to eat their meals, they smuggled passengers to Ahmedcik and Mustafa Prens Loyd ferry in a barge in front of the coal warehouse. While it was possible for them to eat in the lifeboat, their departure from the guard post caused the desertion to occur. Upon this situation, it was understood that the lifeboats should not leave their positions regularly. ${ }^{85}$ If the boat had needed to be

\footnotetext{
${ }^{78}$ BOA.DH.TMIK.M. 247/34

${ }^{79}$ BOA.DH.MUI. $37 / 22$

${ }^{80}$ BOA.DH.TMIK.M.251/35

${ }^{81}$ BOA.DH.ŞFR. 380/64

82 BOA.DH.TMIK.M. 247/34

${ }^{83}$ BOA.DH.TMIK.M. 247/34

${ }^{84}$ BOA.DH.TMIK.M. $252 / 55$

${ }^{85}$ BOA.DH.TMIK.M.251/35
} 
separated, it was recommended to replace it with another viewing boat and pay attention to this issue.

Ahmedcik is a boatman frequently mentioned by the Beirut Pier Commission. Based on the notices, the Ecuador steamer of the Messagerrie company fellah with two boats, and the Italian steamer that came to Beirut with the Jaffa sect, 113 fellaheen at the location of Mintalhars ${ }^{86}$ and Prince Loyd steamer was known to abduct passengers of unknown numbers. ${ }^{87}$ Again, in another declaration dated May 22, 1323 and numbered 100, it was stated that twenty fellaheen were smuggled by the smuggler Ahmedcik to the British Aspirensi ferry in the port. ${ }^{88}$ It is understood that Ahmedcik continued his smuggling repeatedly because he did not receive a penalty for his smuggling.

Although it had been reported before, the fugitives were taken to the Prince Loyd ferry by Ahmedcik and Mustafa, who were put on the boat in front of the casino in the dock and taken to the Prince Loyd ship completely in front of the officers and police officers. It was understood that even the gendarmes did not attempt to prevent passengers even though they saw the smuggling of passengers, while they were required to take care of the duties of the gendarmerie watching towers on the dock and patrolling the dock, as there were French ferries in the port that day. It was deemed necessary for the police officers, officers and naval soldiers who were on duty both at sea and on land to be investigated and punished because they "did not act as if it was their duty to not fulfill their duties". ${ }^{89}$

One of Ahmecik's incidents is illegal goods smuggling. With a report, it was understood that near Mintelhars they imported tenbakü (tobacco smoked with hookah) and forbidden goods into the country without experiencing any difficulties. Reşid Berberi, one of the smugglers who had previously traveled to Piraeus, brought with him fifty bags of tenbacil and banned goods, Martin rifle, cartridges and dynamite, and his partners Mehmed Bekon, İbrahim Zeydan and Mustafa Hulvan, the owner of the Beirut ferry, took them to the beach safely. Then it was handed over to Naim elhurni (?) and Ilyas from the people of Mount Lebanon. As a result of the investigation obtained from various sources, it was understood that the smuggler Ubeyd and his brother Cemil, Ahmedcik, Mehmed Bekon and his stooges were exported to the firewood depots in Mintelhars on Monday with two hundred bags of tenbacil and five hundred rifles and twenty five thousand cartridges and three thousand dynamite. However, the commission delegation stated that the fugitive, except for the pier, did not belong to the commission and stated that they were not allowed to write anything to the province. ${ }^{90}$

The Pier Commission, in the statements written by the gendarmerie commander and the police management on the journalists about the continuous and ongoing smuggling of fellaheen, harmful and forbidden goods on Beirut beaches, stated that the crime and misdemeanor of smuggling was blamed on the scaffolding commission. In response to the complaints against the Beirut pier administration and officers, the scaffolding commission made a statement in an explanatory letter. ${ }^{91}$ According to this, in the scaffolding commission, it was stated that all the existing fifty police officers were employed in the commission twice and were removed upon complaint and that there was no existing officer to be liked by the commission, and if there had been any officer who abused their duty, legal proceedings were made against them. The scaffolding commission delegation deemed itself obliged to perform the pier operation, which was only a few meters, and the Beirut coast was about ten miles and there were 31 police stations in the city of Beirut, which

\footnotetext{
${ }^{86}$ BOA.DH.TMIK.M. 247/34

${ }^{87}$ BOA.DH.TMIK.M. $251 / 35$

${ }^{88}$ BOA.DH.TMIK.M. 247/34

${ }^{89}$ BOA.DH.TMIK.M.252 / 55

${ }^{90}$ BOA.DH.TMIK.M.251/35

${ }^{91}$ BOA.DH.TMIK.M.252 / 55
}

\author{
History Studies \\ www.historystudies.net
}


consisted of nearly one hundred and fifty nations and subjects, and there were fifty police officers and eighty gendarmes, including the police officers. Fourteen of the police officers were working in the pier and the lighthouse, and the thirty-six soldiers of the gendarmerie in the pier, prison, bank and courthouse. The commission declaring that the order and protection of the country was under the responsibility of only thirty six commissioners and police officers and forty-four gendarmes, stated that hundreds of passengers who came to Beirut pier every day were busy at the pier with the examination of their identity and registration, and that nothing could be done against the badness that might occur both from the coast and at sea. He stated that the police officers who were present for the watching had to help in this matter. ${ }^{92}$

In response, the Beirut, Tripoli and Latakia pier commissions were informed to fulfill their duties, to report the problems they encountered to the custody by telegraph, and to prevent the abduction of passengers and forbidden goods from the ports and beaches by giving police, gendarmerie and watching boats to their attendants. ${ }^{93}$ In addition, it was accepted that any corruption that might occur was the joint responsibility of the commission delegation. Moreover, the examination of the identity of the people who came and went to the Beirut pier, the documents of passage, identity and their passports was one of the most important duties of the commission, which was established with the will. The Beirut, Tripoli and Latakia scaffolding commissions were also among their duties to regularly send a monthly table of actions, inspections and proceedings, stating the number, sect and nationality of all people coming and going. In addition to the reports they would send, the journals they would submit to the provincial authority every day would be sealed first by the serasker and then by the officials of the Ministry of Navy and Conquest. Thus, necessary care would be taken to prevent escapes and goods smuggling. With the order of the monarch, the duty of tracking documentation and maintaining the order of each territory at Beirut pier is given to the pier commission; and, Hasan Efendi, who was appointed temporarily for the communication of the Beirut scaffolding commission with the local government, was prepared.

Although some officers had knowledge and participation in smuggling, the first reason that facilitated smuggling was the absence of police for the protection of the large province coast. Secondly, the smugglers who had acquired a wealth of up to twenty thirty thousand liras by acquiring the art of smuggling could not be treated other than fines. Thirdly, foreign ferries were stopping at locations other than the pier and pick up passengers. In this framework, it was deemed necessary to take all kinds of measures to prevent smuggling with a exemplary penalty scheme about smugglers. $^{94}$

The coasts of Syria and Aleppo had become a route preferred by fugitive immigrants after the connection of the Beirut simendifer line with Aleppo. Since Aleppo's Syrian coast is close to the island of Cyprus, the inability to observe these areas became a factor that facilitated the escapes. With the conviction that strict supervision and surveillance was required for the protection of the wider provincial coast, both the provincial governors and the wonderful inspectors were asked to send two or three ferries and steamboats to visit the coasts. In addition, the Beirut and Tripoli pier commissions were ordered by the navy officer with the order of the monarch. The naval officer was given a boat from each of the naval soldiers at the captain of the harbor master at each pier, and it was deemed necessary to carry out observing in and around the port. ${ }^{95}$

However, the areas along the coast where there were no watching towers became suitable for smuggling. Related to this, it was reported that the coastal watching tower, which is located five

\footnotetext{
92 BOA.DH.TMIK.M. 247/34

${ }^{93}$ BOA.DH.TMIK.M.251/35

${ }^{94}$ BOA.DH.MUİ.37/22

${ }^{95}$ BOA.DH.TMIK.M.251/35
} 
hours north of Latakia, was destroyed and that there were no guards in this location, the fellaheen and the Armenians were transferred to the ferries by boat. In this location, the fugitives brought from Mount Lebanon through Hanacorcu and İbrahim Alagar and their refuge in Latakia were smuggled by boat. With the interrogation of the fellows and parents of the fugitives, it was tried to reveal who the boatmen or intermediaries were facilitating the fugitives. ${ }^{96}$

Since the scarcity of naval soldiers did not allow the lifeboat police station to be kept permanently at sea, the police and police could only be helped when there was a notification. ${ }^{97}$

Despite all the measures taken, the wide coastline was used as an opportunity for smugglers. Smuggling continued in locations away from the locations that were always kept under surveillance. ${ }^{98}$

As a result, many people from Beirut, Syria, Aleppo, Lebanon, Jerusalem and the surrounding areas, whose identity were not known, were fleeing to America, and due to these fugitive migrations, there was a decrease in troops and difficulties in procuring jobs to be employed in agriculture. In addition, those who were indebted to the state or accused of murder had the opportunity to escape. The fact that all of the commissars and police officers in Beirut were found jointly with the smugglers, the official places such as the port and the embezzlement allowed the desertion of the fellah and the entry of the Armenians, and the difficulties in the surveillance and containment of the large coast could be mentioned as the reason for this situation. Since the smugglers were not treated in Beirut, the guns, cartridges and other forbidden items brought by these smugglers from the ferries were not examined by the police, and the measures and time of the scaffold commission remained ineffective. ${ }^{99}$

Referring to the fellaheen and goods smuggling, as an extract by the Sevahili Şahane Inspector and Erkan-1 Harb Kaimakam Said Saadi bin Fars; the police commissioner Mirat, who was jointly with the smugglers, and Ramazan, the police officer Kemal, Abdürrahmet, Ali and Hüsni Efendi, the police officer Kemal, Abdürrahmet, Ali and Hüsni Efendi, and the Gendarmerie Sergeant Nesib were definitely removed from Beirut, and they were replaced by honorable police from other provinces, ${ }^{100}$ secondly; it was thought that it would be appropriate to exile smugglers from the Beirut people who were Ottoman subjects such as Ahmet Hariru, Hüseyin Hariru, Mustafa, Mehmed Ferağıl Elcik, Abdüsselam and Sadettin, and Ahmedcik whose name was registered in the redif register, allegedly belonging to France and who had a hand in every smuggling, was exiled to non-coastal areas. ${ }^{101}$

Similarly; in a letter dated June 29, 1323, written to the Ministry of Internal Affairs by the Beirut Sevahili Şahane Inspector Erkan-1 Harb District Governor, the smuggler İsmail Heykel from Tartus had 28 fellaheen of Tartus deserted to Tuzla pier in Cyprus in return for seven liras. As it was understood by the Latakia Pier Commission that he had stayed in Tuzla for about weeks and boarded the Italian Singapore ferry with the fellaheen, he was asked to be taken to a suitable non-coastal area, that was to be exiled, since he had committed the crime of smuggling many times. ${ }^{102}$

The assessment made by the Tesrî-i Muamelat Commission was notified to the Ministry of Defense and the Naval Ministry, the Beirut Province, and the Sevahili Şahane Inspector, Erkan-1

\footnotetext{
${ }^{96}$ BOA.DH.TMIK.M.231 / 44

97 BOA.DH.TMIK.M.252 / 55

${ }^{98}$ BOA.DH.MUI.37/22

${ }^{99}$ BOA.BEO.3115/233601

${ }^{100}$ BOA.DH.TMIK.M.251/35

${ }^{101}$ BOA.DH.TMIK.M. 247/34

102 BOA.DH.TMIK.M.251/44
} 
Harb District Governor, Said Bey, in a letter. ${ }^{103}$ According to this, it was stated that the people who dared smugling explicitly menditoned before were expelled to non-coastal areas in accordance with the order of the monarch provision, and the assistance of the Beirut naval officers regarding the order of the port was necessary and definite. It was declared that unless the previously requested high-speed steamboats and ferries arrive, this mischiefs would not be prevented. Subsequently, it was deemed necessary to carry out legal proceedings against comissars and police officers, who were declared to facilitate smuggling, and to take an urgent serious measure against smuggling in accordance with the order of the monarch, and to send the smugglers whose names were mentioned to the administration of Kastamonu. These smugglers were asked to be arrested in order not to allow their escape to one side.

People named Mahmud, Ahmet Hariri, Hasan Hariri and Mustafa, who were publicly smuggling forbidden and harmful goods and weapons, were ordered to be exiled to Kastamonu. With a password dated August 11, 1323, this decision was conveyed to the Beirut province. This decision was conveyed to the Ministry of Public Security and Kastamonu Province and to the Sevahil-i Şahane Inspector Erkan-1 Harbiye District Governor Sadi Bey in Mersin, and the exile of the aforementioned people to Kastamonu and the notification of their arrival, was asked to pay attention not to allow them to escape anywhere. ${ }^{104}$

In Beirut, police commissioner Mirat, Kemal, Abdurrahmet, Ali, Husni and other police officers and officer Ramazan Efendi on the pier who facilitated the Armenian and fellaheen smugling daringly in Beirut as explained in reports by Sevahil-i Şahane Inspector, Beirut District Governor Said Bey were notified by telegram to the Beirut province that the legal investigation and prosecution required against them to be done by "dismissing" them. ${ }^{105}$ With a dated letter sent to the June 25, 1325 Ministry of Public Security, it was stated once again that those mentioned were exiled in the report, which was declared to be smuggling, and the appointment of persons with the required conditions to the places of the commissioners and police officers, and the measures to be taken in this regard.

\section{Conclusion}

Many farmers and laborers escaped to America from Mount Lebanon province. The fellaheen from Mount Lebanon who fled to America were mostly from the people of Syria, Aleppo and Beirut and were not registered. Only some of them are Muslim people who are obliged to military service. Although fellaheen were forbidden to go to Europe and America for a long time, they fled to America by taking ferryboats from Beirut to go to other Ottoman beaches such as Alexandria, Port Said, Jaffa, Jerusalem and Cyprus. Thus, military service obligations, murder suspects, people who were indebted to the state and those who wanted to go to America from the people immigrated by desertion. As a result of the increasing fugitive migrations, a number of problems arose, such as the decrease in military force and agricultural work. Accordingly, it was required to go to America and other foreign countries for trade and art while preserving their nationality, but those who wanted to go to foreign countries are prohibited from going to foreign countries without bail and guarantee.

The people who wanted to go to America without mürûr tezkeresi were secretly transported to the ferries by land brokers, consular rows and boatmen. Smuggling of fellaheen in Beirut and its environs became a lucrative business which some people acquired as an art for themselves. The import and export of prohibited items such as weapons and ammunition were also carried out with

${ }^{103}$ BOA.DH.TMIK.M.251/35

${ }^{104}$ BOA.DH.TMIK.M.251/35

105 BOA.DH.TMIK.M.251/35 Lef 7 
the smuggled passengers. The fines imposed on them for smuggling did not prevent them from doing this.

The company ferries stopping at other neighboring piers and ports such as Beirut, Tripoli and Latakia took the stowaways and transported them to European ports to go to America. Especially the fellaheen who got on the ferries of the French companies, who regularly came to the port of Beirut, went to America from Marseille. Company steamers made great profits by importing and exporting forbidden goods as well as smuggling of immigrants. In order to prevent this, the relevant embassies were notified of the situation, but no response was received.

It was deemed appropriate to give fines to ferries carrying Mount Lebanon fellaheen without a passport and to the boatmen who smuggled these passengers and similar vehicles, and to treat ship captains who act contrary to the regulations in accordance with the passport regulations.

In order to maintain the ban, a number of measures were implemented to increase surveillance and surveillance at sea and on land. In this context, some of the police and gendarmerie officers in Beirut were assigned to this job. While some measures were taken, such as beach watching towers, watching boats, the supply of fast ferries, and the sailing of lifeboats in turn, effective penalties were arranged. However, the wide coastal line made it difficult to observe and made smuggling convenient. The control of the coastal line divided into parts is left to the pier committees. In this case, the scaffolding officers, police and other officials who had in common with the smugglers made it easier by tolerating the smuggling in return for money. Therefore, they caused the measures taken to be resultless.

Although a legal arrangement of penalties to be executed against the smugglers of the Lebanese people of Mount Lebanon was constantly requested from the Beirut province, it was stated by the Council of State that a order and law declaration, such as a punishment scheme for those who facilitated their escape, was not appropriate. Even though this behavior of the officers and police officers who participated in the fellah smuggling was seen as murder by the Beirut provincial administrative council, they were punished by the Council of State in accordance with the provisions of the relevant laws. As a result of the investigation carried out on the basis of the decision dated August 11,1323, there was no doubt that they were jointly with the smugglers and were deported from their jobs to other districts other than Beirut. Despite the measures, the smugglers with names such as Ahmedcik and İsmail, who dared to smuggle, were decided to be sent to the administration of Kastamonu. In the past, while such smugglers were sent to Rhodes and Alexandria, these boatmen from Beirut were deemed appropriate to be exiled to areas where there was no beach. They were even asked to be arrested in order not to allow their escape anywhere. People named Mahmud, Ahmet Hariri, Hasan Hariri and Mustafa, who were openly smuggling forbidden objects and weapons, were exiled to the Kastamonu temporarily.

In order to maintain the immigration ban, all kinds of measures were taken by the provinces and the government to prevent the immigration of the defectors by escaping. In this context, the deportation of the smugglers detected as a result of the investigation and their joint officers can be considered as an effective punishment scheme. Despite this, the tolerance of the police and their officers against the smugglers in return for bribery rendered the measures ineffective. However, smuggling could not be prevented completely, as the wide coastline made inspection and surveillance difficult.

\author{
History Studies \\ www.historystudies.net
}




\section{References}

Ottoman Archival Documents

BOA.BEO 2711/203258

BOA.BEO. 3115/233601

BOA.BEO 551/41285, BEO 551/41285 lef 2

BOA.BEO 3083/231194

BOA.DH.H. 21/67

BOA.DH.ŞFR.372/126

BOA.DH.ŞFR. 389/26

BOA.DH.ŞFR 203/85

BOA.DH.ŞFR. 288/27

BOA.DH.ŞFR. 365/145

BOA.DH. ŞFR. 218/8

BOA.DH.ŞFR. $389 / 26$

BOA.DH.ŞFR. $380 / 64$

BOA.DH.ŞFR.EUM. 4. ŞB. 1/7, Lef 2

BOA.DH.MUİ. 37/22

BOA.DH.MKT 623/92

BOA.DH.MKT 2335/114

BOA.DH.MKT. 1198/25 Lef 4

BOA.DH.MKT. 2753/2

BOA.DH.MKT. 277/47

BOA.DH.TMIK.M. 252/29

BOA.DH.TMIK.M 251/35, DH.TMIK.M. 251/35 Lef 7

BOA.DH.TMIK.M. 65/56

BOA.DH.TMIK.M. 244/7, DH.TMIK.M. 244/7 Lef 8

BOA.DH.TMIK.M. 252/55

BOA.DH.TMIK.M. 255/25

BOA.DH.TMIK.M. 222/ 8

BOA.DH.TMIK.M. 230/20

BOA.DH.TMIK.M. 247/34

BOA.DH.TMIK.M. 251/44

BOA.DH.TMIK.M. 231/44

BOA.HR.ID. 15/17, HR.İD. 15/17 Lef 2 


\author{
BOA.HR.ID 15/51 \\ BOA.HR.İD. 14/66 Lef 3 \\ BOA.HR.İD. 14/57 \\ BOA.HR.IDD. 15/15 \\ BOA.HR.İD. 14/53 \\ BOA.HR.ID. 15/3 Lef 4 \\ BOA.HR.ID. 15/55 \\ BOA.HR. İD. 15/49 \\ BOA.HR.ID. 15/10 Lef 2. \\ BOA.HR.SYS. 1529/99 \\ BOA.HR.TO 405/67 \\ BOA.ŞD 2279/7 \\ BOA.Y.EE.136/121 \\ BOA.Y.PRK.UM.. 67 /75 \\ BOA.Y.PRK.ASK.249/79
}

\title{
Secondary Sources
}

Baer, Gabriel, Fellah and Townsman in the Middle East Studies in Social History, Frank Cass, London 1982,

Başbakanlık Devlet Arşivleri Genel Müdürlüğü Osmanlı Arşivi Daire Başkanlığı, Osmanlı Belgelerinde Suriye, Publication issue: 129, İstanbul 2013.

Croxton, F.C. (1911). Reports of Immigration Commissions Statistical Review of Immigration 1820-1910, Distribution of Immigrants 1850-1900, Washington: Government Printing Office

Günaydın, Meryem, “Osmanlı Döneminde Suriye Havalisinden Amerika'ya Göçler”, Journal of The Center for Ottoman Studies, Ankara University, 46 /Fall 2019, pp.133-166.

Issawi, Charles, The Economic History of the Middle East 1800-1914 A book of Readings, Chicago: The University of Chicago Press, 1966.

Khater, Akram Fouad, Inventing Home Emigration, Gender, and the Middle Class in Lebanon 1870-1920, University of California Press, London, England 2001.

Gordon, Leland James, American Relations With Turkey 1830-1930 An Economic Interpretation, University of Pennsylvania Press, 1932

Öztürk, Mustafa, "19. Yüzyılın Sonları ile 20. Yüzyılın Başlarında Beyrut ve Çevresi”, Journal of Turkish Studies Türklük Bilgisi Araştırmalarl, Festschrift in honor of Prof. Dr. Özer Ergenç, Cemal Kafadar and Gönül A. Tekin(eds), Volume 52, Cambridge, Aralık 2019, Mass: Harvard University Near EasternLanguages and Civilizations, 161-184.

Parlatır, İsmail, Osmanlı Türkçesi Sözlüğ̈̈, Yargı Yayınevi, Ankara 2009.

Şıvgın, Hale - Günaydın, Meryem, "The Armenian Repatriation 1908-1914, The Question of Nationality and Property", Journal of Gazi Academic View, 8(16), Ankara 2015, pp. 1-40. 